\title{
Feeding Protected Lysine and Methionine Modifies Milk Protein Profile in Grazing Dairy Cows
}

\author{
Mónica Duque Quintero, Martha Olivera-Angel* \\ Department of Agricultural Sciences, University of Antioquia, Biogenesis Research Group, Medellin, Colombia \\ Email: *martha.olivera@udea.edu.co
}

How to cite this paper: Quintero, M.D. and Olivera-Angel, M. (2019) Feeding Protected Lysine and Methionine Modifies Milk Protein Profile in Grazing Dairy Cows. Agricultural Sciences, 10, 214-226. https://doi.org/10.4236/as.2019.102018

Received: January 28, 2019

Accepted: February 25, 2019

Published: February 28, 2019

Copyright (อ 2019 by author(s) and Scientific Research Publishing Inc. This work is licensed under the Creative Commons Attribution International License (CC BY 4.0).

http://creativecommons.org/licenses/by/4.0/

Open Access

\begin{abstract}
The experiment was designed to determine the effect of protected lysine (Lys) and methionine (Met) supply on milk protein profile in grazing dairy cows specifically in the caseins (CNs) and $\alpha$-lactalbumin fractions. Twelve multiparous mid lactation Holstein cows producing $24( \pm 4.76) \mathrm{kg}$ of milk were assigned to one of two treatments (six cows per treatment) during an experimental period of 21 days. In the control (C) group, cows grazed a Pennisetum clandestinum pasture and were supplemented with a commercial concentrate according to milk production. In the Met-Lys treatment, cows received the same ration supplemented with protected Lys and Met. Milk yield and composition and milk protein profile were measured at the start and the end $\left(21^{\text {st }}\right.$ day) of the experimental period. The Tricine-SDS-PAGE and the Gel-Quant Express Analysis (Invitrogen) software were used to determine milk protein composition. Statistical analysis was performed using the SAS's PROC MIXED procedure through a mixed model that included the animal as a random effect and the treatments as a fixed effect adjusted by covariables. Milk production averaged $23.7( \pm 2.0) \mathrm{kg} \mathrm{cow}^{-1}$ day $^{-1}$ without differences between treatments $(P<0.96)$. Yield of fat corrected milk $(4 \% \mathrm{FCM})$ tended $(P<$ $0.10)$ to increase in the Met-Lys treatment $\left(26.0 \mathrm{~kg} \mathrm{cow}^{-1} \mathrm{day}^{-1}\right)$ compared to $\mathrm{C}\left(24.2 \mathrm{~kg} \mathrm{cow}^{-1} \mathrm{day}^{-1}\right)$. Milk protein content $(\mathrm{g} / \mathrm{kg})$ did not differ $(\mathrm{C}=30.4$; Met-Lys $=31.1)$ and lactose content tended $(P<0.08)$ to be higher in the Met-Lys (47.4) group compared to C (45.9). Milk protein content $(\mathrm{g} / \mathrm{kg})$ of aS1-CN resulted higher $(P<0.046)$ in Met-Lys $(10.58)$ compared to $\mathrm{C}(9.44)$. Concentration of $\beta$-CN also increased $(P<0.05)$ after protected aminoacid supply $(\mathrm{C}=9.58$; Met-Lys $=10.35)$. It can be concluded that milk protein composition was improved by protected Lys-Met supply without altering other compositional parameters of milk composition. Milk nutritional quality and its potential yield for cheese-making were positively enhanced.
\end{abstract}




\section{Keywords}

Grazing Dairy Cows, Protected Amino Acids, Milk Proteins

\section{Introduction}

Milk is an important food source both, in its natural form and also in a wide variety of processed dairy products. Approximately $80 \%$ of milk proteins are made up of caseins (CNs) being some of the most valuable components of dairy products because of their nutritional value and their important role and influence in the quality of cheese production [1]. Milk proteins and related peptides are classified into four different groups: CNs made up of $\alpha \mathrm{S} 1-\mathrm{CN}, \alpha \mathrm{S} 2-\mathrm{CN}, \beta-\mathrm{CN}$, and $\kappa$-CN; serum proteins which include $\alpha$-lactalbumin ( $\alpha$-LA), $\beta$-lactoglobulin ( $\beta$-Lg), bovine serum albumin (BSA); immunoglobulins (Igs) and other minor milk serum proteins, such as proteases and proteins of the fat globule membranes [2]. CNs are a product of the expression of four genes which encode four polypeptide chains $\alpha \mathrm{S} 1-\mathrm{CN}, \alpha \mathrm{S} 2-\mathrm{CN}$ in a $4: 1$ ratio, $\beta$-CN and $\kappa$-CN in a 4:1 ratio. $\mathrm{CNs}$ undergo posttranscriptional modifications, which allow them to interact with calcium phosphate $\left(\mathrm{Ca}_{3}\left(\mathrm{PO}_{4}\right)_{2}\right.$ and thus form micelles. The phosphoserine cluster of $a \mathrm{~S} 1-\mathrm{CN}, \alpha \mathrm{S} 2-\mathrm{CN}$ and $\beta$-CN stabilizes phosphate nanoclusters of calcium, crossing each other and thus increasing the size of the micelles [3] [4] [5]. Phosphorylation levels of $\alpha \mathrm{S}-\mathrm{CN}$, according to some authors, could stabilize the internal structure of the micelle, which would positively affect the properties of nutritional and industrial milk [3] [6]. The following variations in CN types have been found in the Bos genus [7]: 9 of $\alpha \mathrm{S} 1-\mathrm{CN}$ (A, B, C, D, E, F, G, H, I), 4 of $\alpha \mathrm{S} 2-\mathrm{CN}(\mathrm{A}, \mathrm{B}, \mathrm{C}, \mathrm{D}), 12$ of $\beta$-CN (A1, A2, A3, B, C, D, E, F, G, H1, H2, I), 14 of $\kappa$-CNs (A, A1, B, B2, C, D, E, F1, F2, G1, G2, H, I, J), 3 of $\alpha$-LA 100 (A, B, C), and 11 of $\beta$-Lg (A, B, C, D, E, F, G, H, I, J, W) [8].

The protein synthesis in the mammary gland depends on the availability of specific amino acids (AAs) [9] being Met and Lys considered to be the most important ones [10] [11] [12]. These two AAs are the most limiting in dairy production grazing systems in which concentrates based on soy cake and corn grain are fed [13]. This deficiency can be verified by comparing the amino-acid profile of these feedstuffs with that of microbial protein and bovine milk [14].

The production and manufacture of CNs occur in the rough endoplasmic reticulum and their phosphorylation takes place in the Golgi apparatus being this event essential for the binding of organic and inorganic calcium and other metal ions. Phosphorylation is required for the building and integrity of micelles, and it has a potential influence on functional properties such as rennet-induced coagulation [15]. Although the four CNs $(\alpha \mathrm{S} 1-\mathrm{CN}, \alpha \mathrm{S} 2-\mathrm{CN}, \beta-\mathrm{CN}$, and $\kappa$-CN) are phosphoproteins, $\alpha \mathrm{S} 1-\mathrm{CN}$ and $\alpha \mathrm{S} 2-\mathrm{CN}$ showed higher levels of phosphorylation and their phosphorylation profiles are more heterogeneous than those of $\beta$-CN and $\kappa$-CN. The amount of $\alpha \mathrm{S} 1-\mathrm{CN}$ is $35 \%$ of the total $\mathrm{CN}$ in bovine milk, 
and its phosphorylation level is one of the factors affecting the industrial properties of milk. Therefore, there is a growing interest to know if any dietary factors may contribute to the variation in the CNs profile of milk [16]. The study was designed to determine changes in the composition of several milk proteins such as CNs and $\alpha$-LA when lactating dairy cows were supplemented with protected Met and Lys.

\section{Materials and Methods}

\subsection{Animals and Treatments}

The experiment was conducted at the "Betania" farm, located in Santa Rosa de Osos (Antioquia, Colombia) at 2500 meters above sea level with an average temperature of $14^{\circ} \mathrm{C}$ and a relative humidity of $79 \%$. The average annual rainfall is $2500 \mathrm{~mm}$. Twelve lactating Holstein cows ( $547 \pm 56.1 \mathrm{~kg}$ body weight) in their second to fourth lactation with $124.8( \pm 14.0)$ days in milk and a body condition score of $3.02( \pm 0.17)$ were used. At the start of the experiment cows were producing $24( \pm 4.76) \mathrm{kg}$ milk with $28.9( \pm 1.7) \mathrm{g} / 100 \mathrm{~g}$ protein and $34.5( \pm 4.2) \mathrm{g} / 100 \mathrm{~g}$ fat. Cows grazeda pasture composed by kikuyugrass (Pennisetum clandestinum) in a rotational grazing system in the same paddock throughout the experiment with fresh water available all the time. Herbage biomass $\left(\mathrm{kg} \mathrm{DM} \mathrm{ha}^{-1}\right)$ was estimated by cutting samples of forage at the ground level with manual scissors in an area delimited by a metal frame of $0.125 \mathrm{~m}^{2}$ in a total cutting area of $1 \mathrm{~m}^{2}$ in each sampling. The total sample (8 subsamples of $\left.0.125 \mathrm{~m}^{2}\right)$ was dried $\left(65^{\circ} \mathrm{C}\right.$ for 48 hours) to determine the dry matter (DM) content. The area of the daily strip was established according to pasture allowance and adjusted to offer $30 \mathrm{~kg} \mathrm{DM}$ $\mathrm{cow}^{-1} \mathrm{day}^{-1}$ using electric fences. The cows were milked twice daily at 4:00 a.m. and 2:00 p.m.

The animals were randomly divided into two groups of six cows balanced by lactation number $(\mathrm{C}=2.83 \pm 0.98$ and Met-Lys $=2.67 \pm 0.82$, respectively), body condition score (BCS, $3.00 \pm 0.16$ and $3.08 \pm 0.20)$ and days in milk $(131 \pm 13.42$ and $120 \pm 13.86)$. In the $C$ treatment, cows grazed the kikuyu pasture and were individually supplemented with a commercial concentrate during each milking time according to milk production. In the Met-Lys treatment, cows received the same ration with the addition of protected Lys and Met in the concentrate. The chemical composition of the pasture and the concentrate (Table 1) was determined according to methods described by AOAC [17]. Non-structural carbohydrates (NSC) and net energy of lactation $\left(\mathrm{NE}_{\mathrm{L}}\right)$ were calculated using the following equations: $\mathrm{NSC}=100-(\% \mathrm{NDF}+\% \mathrm{CP}+\% \mathrm{EE}+\% \mathrm{Ash}), \mathrm{NE}_{\mathrm{L}}=$ $0.0245^{\star} \mathrm{TDN}(\%)-0.12$. Met and Lys concentration in the forage and concentrate were reported previously [18].

The Amino-Cow software [19] was used to estimate cows requirements of Met and Lys. Data showed a Met and Lys deficiency of $29.7 \%$ and $20.5 \%$ respectively in the total diet. In consequence, protected-Met (Mepron', Evonik, Degussa AG, Germany) and protected-Lys (AjiProTM-L Ajinomoto, Tokyo, Japan) 
Table 1. Chemical composition of the kikuyu pasture and concentrate.

\begin{tabular}{ccccc}
\hline & Kikuyu & Concentrate & RP-Met & RP-Lys \\
\hline DM, g/kg & 109 & 902 & 982 & 974 \\
CP, g/kg DM & 182 & 171 & 439 & 563 \\
TDN, g/kg DM & 604 & 760 & - & - \\
EE, g/kg DM & 31.2 & 39 & 10 & 427 \\
NDF, g/kg DM & 564 & 218 & 30 & - \\
ADF, g/kg DM & 314 & 165 & - & - \\
ADL, g/kg DM & 63.5 & 38.3 & & - \\
ADICP, g/kg DM & 18 & 11 & - & 3.262 \\
NSC, g/kg DM & 114 & 472 & & \\
NE, Mcal/kg DM & 1.36 & 1.77 & 1.941 & - \\
Ash, g/kg DM & 109 & 100 & 1.501 & - \\
Calcium, g/kg DM & 3.4 & - & - & 10.02 \\
Phosphorus, & 3.1 & - & - & 377 \\
Soy lecithin, g/kg DM & - & - & - & \\
Met, g/kg DM & 3.1 & 5.8 & 453 & - \\
Lys, g/kg DM & 9.5 & 10.9 & - & \\
\hline
\end{tabular}

RPMet: Rumen protected methionine (Mepron), LysP: Rumen protected lysine (AjiPro-L); DM: dry matter; $\mathrm{CP}$ : Crude protein, TDN = total digestible nutrients; EE: Ether extract, NDF: Neutral detergent fiber, ADF: Acid detergent fiber, ADL: Acid detergent lignin, ADICP: Acid detergent insoluble crude protein, NSC: Non-structural carbohydrates $=100-(\% \mathrm{NDF}+\% \mathrm{CP}+\% \mathrm{EE}+\%$ Ash $)$, NEL: Net energy of lactation $=$ 0.0245 *TDN $(\%)-0.12$, Met: Methionine, Lys: Lysine.

were added to the concentrate in sufficient quantities $(7.03 \pm 2.93 \mathrm{~g}$ of P-Met and $23.9 \pm 3.82 \mathrm{~g}$ of P-Lys) to be released in the small intestine. The cows were offered the experimental diets from days $1^{\text {st }}$ to $21^{\text {th }}$ of the trial.

\subsection{Pasture and Concentrate Intake}

Pasture and concentrate intakes were estimated using chromium oxide $\left(\mathrm{Cr}_{2} \mathrm{O}_{3}\right)$ as an external marker and ADL as an internal marker [20] [21]. Chromium oxide was dosed ( $10 \mathrm{~g} /$ day) twice daily after the morning and afternoon milkings in $5 \mathrm{~g}$ of shredded paper during 9 days which corresponds to day 12 after the start of the experimental period.: The first 6 days were used to attain the equilibrium between intake and excretion of the marker. On the $7^{\text {th }}$ day, fecal samples $(250 \mathrm{~g}$ each) were taken manually from rectum immediately after morning and afternoon milkings during three consecutive days. Fecal samples were stored at $-20^{\circ} \mathrm{C}$, dried at $60^{\circ} \mathrm{C}$ in a forced-draught oven and were ground to pass a $1-\mathrm{mm}$ mesh sieve and stored in plastic containers for subsequent chemical analysis. Fecal samples were analyzed for chromium oxide using an atomic absorption spectrophotometer, according to the methodology described by Souza et al. [22]. Concentrate DM intake was measured by weighing the quantities offered and refused. Fecal production and forage DMI were estimated using the following formulae as proposed by [23]. 


$$
\mathrm{FP}((\mathrm{g} \mathrm{DM} / \text { cow }) / \mathrm{d})=\frac{(\text { Chromium administered, } \mathrm{g} / \mathrm{d})}{\text { Chrome concentration in feces, } \mathrm{g} / \mathrm{g} \mathrm{DM}}
$$

where $\mathrm{FP}=$ Fecal production, $\mathrm{g}$ of $\mathrm{DM} /$ day.

$$
\operatorname{DMIf}(\mathrm{kg} / \mathrm{cow} / \mathrm{d})=\frac{(\text { ADL feces } * \text { FP })-(\text { ADLc } * \text { DMIc })}{\operatorname{ADLf}}
$$

DMIf = Dry matter intake of the forage, $\mathrm{kg} / \mathrm{cow} /$ day, $\mathrm{FP}=$ Total fecal production, $\mathrm{kg} \mathrm{DM} / \mathrm{day}, \mathrm{ADL}$ feces = Acid detergent lignin found in the animal's feces, $\%, A D L c=$ Acid detergent lignin of the concentrated food, \%, DMIc $=$ Dry matter intake of the concentrated food, $\mathrm{kg} /$ cow/day, ADLf = Acid detergent lignin of the forage. The fecal chromium recovery rate was assumed to be $80 \%$. Total intake was computed as pasture plus concentrate intake.

\subsection{Sampling Measurements and Laboratory Procedures}

The sampling protocols were accepted by the Ethics Committee of the University of Antioquia (Procedural number: 71, June 17, 2011). Milk production was daily and individually measured and milk samples were collected, composited according to the corresponding volume measured at each milking time and analyzed by infrared spectrophotometry (MilkoScanTM; FOSS Electric, Hillerod, Denmark) according to ISO/IDF standard method. Yield of $4 \%$ FCM was computed using the following formula: $4 \% \mathrm{FCM}=(0.4 \times$ milk production $)+(15 \times$ fat production). On days $1^{\text {st }}$ and $21^{\text {st }}$ milk samples $(15 \mathrm{~mL})$ were also assayed for $\mathrm{CNs}$ and $\alpha$-LAcontent. The relative semiquantification of protein concentrations was performed using a calibration curve with BSA of $66-\mathrm{kDa}$ molecular weight (BSA Standards ELISA Quantitation Set, Cat. No. 23209, Thermo Fisher Scientific Inc., Rockford IL USA). Dilutions of BSA were made at concentrations of $1.000,2.500,1.250,625,312.5,156.25 \mu \mathrm{g} / \mathrm{ml}$, corroborated in the ELISA kit, at $562 \mathrm{~nm}$ (microplates reader ELx800NB). The different BSA concentrations were deposited in Tricine-SDS-PAGE gels (see Figure 1). After migration over a 6 h,

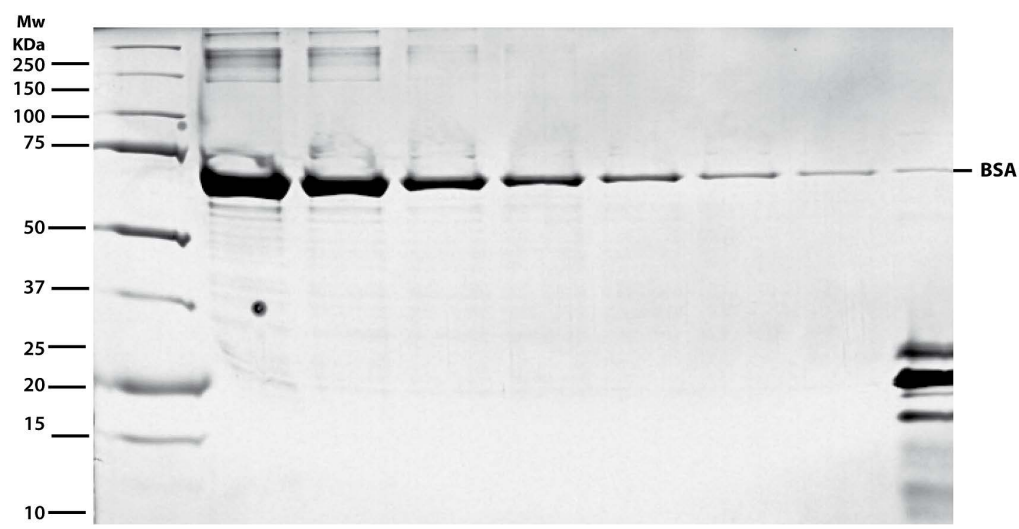

Figure 1. Electrophoresis pattern of bovine serum albumin (BSA) performed with Tricine-SDS-PAGE gels to obtain the standard curve. Line 1. Bio-Rad molecular-weight marker (Precision Plus protein Dual Color Standards). Lines 2 - 8: Serial dilutions of bovine serum albumin (BSA, 97\% purity) with a molecular weight of $66 \mathrm{kDa}$. 
photos of the gels were taken with the DNR's Gel capture mini software (Invitrogen), and the areas and densities of the bands obtained with the GelQuant Express Analysis software (Invitrogen) were analyzed. A standard curve of the densities of the bands and their concentration was plotted, which makes it possible to establish the regression equation used to estimate the concentrations of the samples of interest.

\subsection{Individual Determination of Milk Proteins $(\alpha \mathrm{S} 1, \alpha \mathrm{S} 2, \beta, \kappa, \alpha$-LA)}

Pre-Fractionation of the Sample

The milk fat was removed and $2 \mathrm{~mL}$ of each sample was centrifuged for $15 \mathrm{~min}$ at 2500 relative centrifugal force. The soluble fraction was extracted and $10 \mu \mathrm{L}$ were diluted in $240 \mu \mathrm{L}$ of distilled water (1:25). Separation of lactoproteins: One-dimensional electrophoresis was performed using Mini-Protean III Cell Electrophoresis (Bio-Rad Laboratories, Richmond, CA) and Tricine-SDS-PAGE gels [24]. The separation gels according to [25], were $10 \% \mathrm{~T}, 3 \% \mathrm{C}$, and the concentration gel of $4 \% \mathrm{~T}$ and $3 \% \mathrm{C}$ that separates proteins in molecular-weight ranges of 5 - $30 \mathrm{kDa}$.

The conditions for the protein migration program in electrophoresis were 40 $\min \times 30 \mathrm{~V}$ (constant) and then $6-7 \mathrm{~h}$ at $40 \mathrm{~mA}$ (constant current). Gels were stained at room temperature with Coomassie Brilliant Blue R-250 under constant stirring conditions for $20 \mathrm{~min}$ [26]. They were destained for $16 \mathrm{~h}$ while being agitated. DNR Bio-imaging Systems (MiniBIS Pro) was used for the photos. The semiquantification of the different proteins was carried out on the basis of the color intensity and individual areas of the bands of each lactoprotein in each of the samples, using the GelQuant Express Analysis software (Invitrogen) (See Figure 2).

\section{Statistical Analysis}

Data were analyzed using a mixed model considering the animals as a random effect and the treatments as a fixed effect. Milk production at the start of the trial, days in milk and body condition score were used as covariates. Differences were considered as significant with $P<0.05$ and trends with $P<0.1$, using the SAS's LSMEANS procedure [28].

\section{Results}

\subsection{Chemical Composition of the Diet and Intake}

According to pre-planned design, intakes of protected Met and Lys resulted higher in the Met-Lys treatment (Table 2) due to the increased supply of rumen protected AA.

\subsection{Milk Production and Milk Protein Composition}

Supplementation with rumen-protected Met and Lys modified milk protein profile 


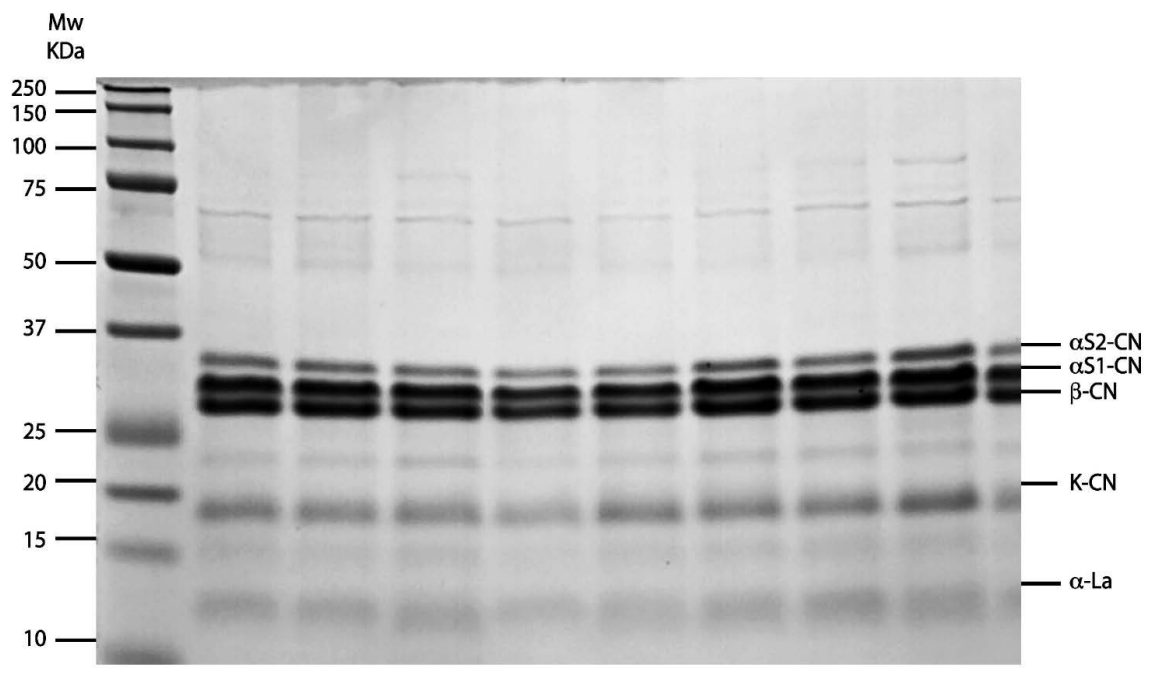

Figure 2. Electrophoresis patterns of bovine caseins $(\mathrm{CN})$ and $\alpha$-LA obtained from Tricine-SDS-PAGE gels. Line 1. Bio-Rad molecular-weight marker (Precision Plus Protein Dual Color Standards). From top to bottom, with molecular weights of 250, 150, 100, 75, $50,37,25,20,15,10 \mathrm{KDa}$. Line 2 - 10. Bovine milk samples assessed, corresponding to caseins $\alpha \mathrm{S} 2-\mathrm{CN}(25,266 \mathrm{KDa}), \alpha \mathrm{S} 1-\mathrm{CN}(23,615 \mathrm{KDa}), \beta$-CN $(23,983 \mathrm{KDa}), \kappa$-CN $(19,037$ $\mathrm{KDa}$ ) according to [27]. Line $2,4,6,8,10$ corresponding to control cow samples and line $3,5,7,9$ to experimental cow samples.

Table 2. Chemical composition of the experimental diets and dry matter intake (DMI) in lactating dairy cows supplemented with protected methionine (Met) and lysine (Lys).

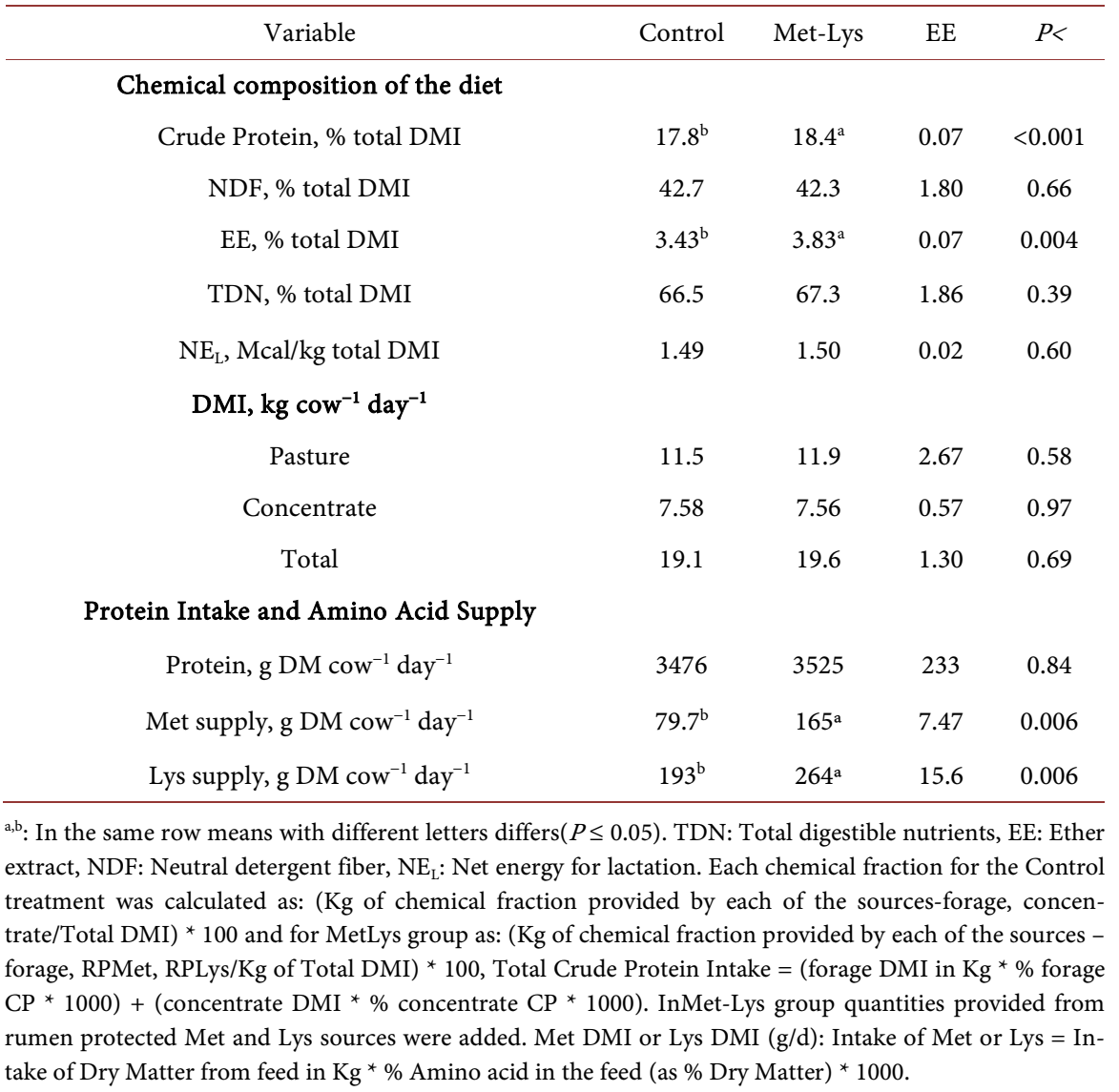


(Table 3) increasing the production of $\alpha$ - $\mathrm{CN}$ and $\beta$-CN $(P<0.05)$. There were no significant effects on yields of milk and $4 \% \mathrm{FCM}$, concentration of protein and $\kappa$-CN, $\alpha \mathrm{S} 2-\mathrm{CN}$, or $\alpha \mathrm{La}$.

\section{Discussion}

Methionine and Lys are considered as the most limiting AAs for milk yield and protein production in pasture-based diets for lactating dairy cows but the addition of these protected AAs in the concentrate increased Met and Lys intake (Table 2). The potential improvement in the AA balance in turn increased milk protein concentration. In addition, Lys and Met are recognized as the limiting AAs for milk production directing the mRNA expression of the JaK-STAT and mTOR pathways and regulating both, the production of protein and the expression of AA transporters at the epithelial cells level of the mammary gland [29] [30]. In addition, it was reported that Lys and Met increase contents of some milk proteins [31] and the presence of Met and leucine in $\alpha \mathrm{S} 1-\mathrm{CN}$ and leucine in $\beta$-CN respectively has been documented [32].

These findings from the literature are consistent with results observed in the present experiment and partially explain the observed increase in $\alpha \mathrm{S} 1-\mathrm{CN}$ and $\beta$-CN levels as well as the increase in milk production observed in cows supplemented with rumen-protected Lys and Met. The $\alpha \mathrm{S} 1-\mathrm{CN}$ is a highly phosphorylated protein, and phosphorylation increases its chaperone activity thereby increasing its ability to stabilize and increase the growth of micelles [33] [34]. It is well-known that the stability and size of micelles improve the industrial qualities of milk, especially its cheese yield. It was reported that the high concentration of the $a \mathrm{~S} 1-\mathrm{CN}$ isoform $(\alpha \mathrm{S} 1-\mathrm{CN}-8 \mathrm{P})$ in bovine milk has a great benefit in the production of raw cheese curd because this protein is hydrolyzed more efficiently by the chymosin during maturity [35] [36].

Table 3. Milk yield and milk protein concentrations in lactating dairy cows supplemented with protected methionine (Met) and lysine (Lys).

\begin{tabular}{ccccc}
\hline Variables & Control & Met-Lys & EE & $P$ \\
\hline Milk yield, $\mathrm{kg} \mathrm{cow}^{-1}$ day $^{-1}$ & 23.7 & 23.8 & 2.05 & 0.96 \\
Yield of 4\% FCM, cow ${ }^{-1}$ day $^{-1}$ & 24.2 & 26.0 & 3.42 & 0.10 \\
Milk lactose content, g/kg & 45.9 & 47.4 & 0.69 & 0.08 \\
Milk protein content, g/kg & 30.4 & 31.1 & 0.692 & 0.159 \\
$\alpha$ S1-CN, g/kg & $9.44^{\mathrm{b}}$ & $10.58^{\mathrm{a}}$ & 0.593 & 0.046 \\
$\alpha \mathrm{S} 2-\mathrm{CN}, \mathrm{g} / \mathrm{kg}$ & 2.55 & 2.94 & 0.582 & 0.125 \\
$\beta$-CN, g/kg & $9.58^{\mathrm{b}}$ & $10.35^{\mathrm{a}}$ & 0.592 & 0.050 \\
$\kappa$-CN, g/kg & 3.25 & 3.49 & 0.572 & 0.663 \\
$\alpha \mathrm{La}, \mathrm{g} / \mathrm{kg}$ & 1.13 & 1.20 & 0.702 & 0.159 \\
\hline
\end{tabular}

\footnotetext{
${ }^{\mathrm{a}, \mathrm{b}}$ : In the same row means with different letters differs $(p<0.05) .4 \%$ FCM: Fat corrected milk $(0.4 \times$ milk production $)+(15 \times$ production of fat $), \alpha \mathrm{S} 1-\mathrm{CN}: \alpha \mathrm{S} 1$ Casein, $\alpha \mathrm{S} 2-\mathrm{CN}: \alpha \mathrm{S} 2$ casein, $\beta$-CN: $\beta$-casein, $\kappa$-CN: $\kappa$ casein, $\alpha$-LA: lactalbumin, EE: Standard error.
} 
Recent studies have demonstrated the important role of some AAs in the diet due to their effects on the transcription and translation of genes in the mammary gland [37]. When Met and Lys were added (in vitro) to bovine mammary gland cells at a 3:1 ratio, an effect on the expression of related genes was observed with the transcription and translation of milk proteins, such as CSN1S1, CSN1S2, CSN2, CSN3, LALBA, JAK2, STAT5, ELF5, mTOR, and EIF4EBP1 which subsequently led to an increase in the $\mathrm{CN}$ synthesis [30]. It is also very important to point out that the cheese yield (grams of dry cheese/100g of milk protein) is improved when milk was selected from cows with high concentrations of $\alpha \mathrm{S} 1-\mathrm{CN}, \beta-\mathrm{CN}$, and $\kappa$ - $\mathrm{CN}$ [32].

The $\alpha \mathrm{S} 1-\mathrm{CN}$, the most prevalent form of $\mathrm{CNs}$ in bovine milk, has antioxidant properties with elimination of free radicals. In turn, this protein contains casecid in which exhibits in vitro activity against Staphylococcus, Sarcina, Bacillus subtilis, Diplococcus pneumoniae, and Streptococcus pyogenes [33]. The $\beta$-CN and its fragments have been implicated in numerous biological functions, such as the $f(63-680)$ and $f(8191-103)$, which has been reported as an activator of macrophage phagocytosis and peroxidase release. Apart from stimulating the proliferation of lymphocytes and macrophages, it promotes the synthesis of antibodies and the regulation of cytokines [38] [39]. The $\beta$-CN is also a source of peptides such as casomorphins that exhibit opioid activity, bind to receptors in the intestinal lumen and act as exogenous modulators of motility, permeability, and release of intestinal hormones. Because of these reasons, there is currently a great interest for the possible nutraceutical role of $\beta$-CN in cases of diarrhea [40].

The 4:1 ratio between $\alpha \mathrm{S} 1-\mathrm{CN}$ and $\alpha \mathrm{S} 2-\mathrm{CN}$ and between $\beta-\mathrm{CN}$ and $\kappa$-CN reported by [2] was not observed in this study, possibly because of the sensitivity of the analytical technique used here. Among many other studies related to ours, significant differences in $\alpha$ - $\mathrm{CN}$ and $\beta$-CN concentrations were reported without determining if the change was in $\alpha \mathrm{S} 1-\mathrm{CN}$ or $\alpha \mathrm{S} 2-\mathrm{CN}$ [41]. On the other hand, the effect of rumen-protected Met supply on grazing systems in New Zealand was reported to decrease the $\beta$-CN production alone [42].

It is concluded that feeding rumen-protected Met and Lys to grazing dairy cows supplemented with concentrates based on soy cake and corn grain positively modified milk protein profiles by increasing the levels of $\alpha \mathrm{S} 1-\mathrm{CN}$ and $\beta$-CN without affecting the total milk protein content but increasing the yield of $4 \%$ FCM. These results justify the search for additional information up to the achievement of the best diets so that cows are able to express all their qualitative and quantitative potential for milk production.

\section{Acknowledgements}

The authors thank COLCIENCIAS for the doctoral scholarship, the Antioquia University for funding this study, Ajinomoto and Evonik for supplying the rumen-protected aminoacid and providing technical assistance and the Department of Agrarian Sciences and the University of Antioquia. The collaboration 
in the writing and review of the manuscript by Dr. Gerardo Gagliostro is also appreciated.

\section{Conflicts of Interest}

The authors declare no conflicts of interest regarding the publication of this paper.

\section{References}

[1] Brophy, B., Smolenski, G., Wheeler, T., Wells, D., L'Huillier, P. and Laible, G. (2003) Cloned Transgenic Cattle Produce Milk with Higher Levels of $\beta$-Casein and $\kappa$-Casein. Nature biotechnology, 21, 157-162. https://doi.org/10.1038/nbt783

[2] Thao, T.L., Hilton C.D. and Lotte B.L. (2017) Proteomics of Major Bovine Milk Proteins: Novel Insights. International Dairy Journal, 67, 2-15. https://doi.org/10.1016/j.idairyj.2016.11.016

[3] De Kruif, C. and Holt, C. (2003) Casein Micelle Structure, Functions and Interactions. In: Advanced Dairy Chemistry-1 Proteins, Springer, 233-276.

https://doi.org/10.1007/978-1-4419-8602-3_5

[4] De Kruif, C.G., Huppertz, T., Urban, V.S. and Petukhov, A.V. (2012) Casein Micelles and Their Internal Structure. Advances in Colloid and Interface Science, 171, 36-52. https://doi.org/10.1016/j.cis.2012.01.002

[5] Dalgleish, D.G. and Corredig, M. (2012) The Structure of the Casein Micelle of Milk and Its Changes during Processing. Annual Review of Food Science and Technology, 3, 449-467. https://doi.org/10.1146/annurev-food-022811-101214

[6] Hoagland, P., Unruh, J., Wickham, E. and Farrell, H. (2001) Secondary Structure of Bovine aS2-Casein: Theoretical and Experimental Approaches. Journal of Dairy Science, 84, 1944-1949. https://doi.org/10.3168/jds.S0022-0302(01)74636-X

[7] Farrell Jr, H., Jimenez-Flores, R., Bleck, G., Brown, E., Butler, J., Creamer, L., Hicks, C., Hollar, C., Ng-Kwai-Hang, K. and Swaisgood, H. (2004) Nomenclature of the Proteins of Cows' Milk-Sixth Revision. Journal of Dairy Science, 87, 1641-1674. https://doi.org/10.3168/jds.S0022-0302(04)73319-6

[8] Caroli, A., Chessa, S. and Erhardt, G. (2009) Invited Review: Milk Protein Polymorphisms in Cattle: Effect on Animal Breeding and Human Nutrition. Journal of Dairy Science, 92, 5335-5352. https://doi.org/10.3168/jds.2009-2461

[9] Bionaz, M. and Loor, J.J. (2011) Gene Networks Driving Bovine Mammary Protein Synthesis during the Lactation Cycle. Bioinformatics and Biology Insights, 5, 83-98. https://doi.org/10.4137/BBI.S7003

[10] Hanigan, M., Crompton, L., Bequette, B., Mills, J. and France, J. (2002) Modelling Mammary Metabolism in the Dairy Cow to Predict Milk Constituent Yield, with Emphasis on Amino Acid Metabolism and Milk Protein Production: Model Evaluation. Journal of Theoretical Biology, 217, 311-330.

https://doi.org/10.1006/jtbi.2002.3037

[11] Rius, A., Appuhamy, J., Cyriac, J., Kirovski, D., Becvar, O., Escobar, J., McGilliard, M., Bequette, B., Akers, R. and Hanigan, M. (2010) Regulation of Protein Synthesis in Mammary Glands of Lactating Dairy Cows by Starch and Amino Acids. Journal of Dairy Science, 93, 3114-3127. https://doi.org/10.3168/jds.2009-2743

[12] Bionaz, M., Hurley, W. and Loor, J. (2012) Milk Protein Synthesis in the Lactating Mammary Gland: Insights from Transcriptomics Analyses. In: Milk Protein, InTech, 285-324. https://doi.org/10.5772/46054 
[13] Galili, G. and Amir, R. (2012) Fortifying Plants with the Essential Amino Acids Lysine and Methionine to Improve Nutritional Quality. Plant Biotechnology Journal, 11, 211-222. https://doi.org/10.1111/pbi.12025

[14] Vyas, D. and Erdman, R. (2009) Meta-Analysis of Milk Protein Yield Responses to Lysine and Methionine Supplementation. Journal of Dairy Science, 92, 5011-5018. https://doi.org/10.3168/jds.2008-1769

[15] Phadungath, C. (2005) Casein Micelle Structure: A Concise Review. Songklanakarin Journal of Science and Technology, 27, 201-212.

[16] Fang, Z.H., Bovenhuis, H., Delacroix-Buchet, A., Miranda, G., Boichard, D., Visker, M. and Martin, P. (2017) Genetic and Nongenetic Factors Contributing to Differences in $\alpha$ S-Casein Phosphorylation Isoforms and Other Major Milk Proteins. Journal of Dairy Science, 100, 5564-5577. https://doi.org/10.3168/jds.2016-12338

[17] Association of Official Analytical Chemists AOAC (2005) Official Methods of Analyses. 18th Edition, AOAC, Gaithersburg.

[18] Duque, Q.M., Rosero, N.R. and Olivera, A.M. (2017) Digestion of Dry Matter, Crude Protein and Amino Acids of the Diet Dairy Cows. Agronomía Mesoamericana, 28, 341-356.

[19] Adisseo, A.C. (2007) The Mepron Dairy Ration Evaluator. Version 3.5.1. Degussa Corp., Hanau.

[20] Correa, H., Pabón, M. and Carulla, J. (2009) Estimación del consumo de materia seca en vacas Holstein bajo pastoreo en el trópico alto de Antioquia. Livestock Research for Rural Development, 21, 4. http://www.lrrd.org/lrrd21/4/corr21059.htm

[21] Fukushimaa, R., Kerleya, M., Ramos, M., Porter, J. and Kallenbach, R. (2015) Comparison of Acetyl Bromide Lignin with Acid Detergent Lignin and Klason Lignin and Correlation with in Vitro Forage Degradability. Animal Feed Science and Technology, 201, 25-37. https://doi.org/10.1016/j.anifeedsci.2014.12.007

[22] Souza, N., Detmann, E., Pina, D., Valadares, F.S., Sampaio, C., Queiroz, A., et al. (2013) Evaluation of Chromium Concentration in Cattle Feces Using Different Acid Digestion and Spectrophotometric Quantification Techniques. Arquivo Brasileiro de Medicina Veterinária e Zootecnia, 65, 1472-1482. https://doi.org/10.1590/S0102-09352013000500028

[23] Santos, S.A., Valadares, F.S., Detmann, E., Valadares, R., Ruas, J., Prados, L., et al. (2012) Intake, Digestibility and Nitrogen Use Efficiency in Crossbred F1 Holstein $\times$ Zebu Grazing Cows. Revista Brasileira de Zootecnia, 41, 1025-1034. https://doi.org/10.1590/S1516-35982012000400027

[24] Pardo, M.F. and Natalucci, C.L. (2002) Electrophoretic Analysis (Tricine-SDS-PAGE) of Bovine Caseins. Acta Farmacéutica Bonaerense, 21, 57-60.

[25] Schägger, H. (2006) Tricine-SDS-PAGE. Nature Protocols, 1, 16-22. https://doi.org/10.1038/nprot.2006.4

[26] Kim, Y., Atalla, H., Mallard, B., Robert, C. and Karrow, N. (2011) Changes in Holstein Cow Milk and Serum Proteins during Intramammary Infection with Three Different Strains of Staphylococcus aureus. BMC Veterinary Research, 7, 51. https://doi.org/10.1186/1746-6148-7-51

[27] Feligini, M., Bonizzi, I., Buffoni, J.N., Cosenza, G. and Ramunno, L. (2009) Identification and Quantification of $\alpha \mathrm{S} 1, \alpha \mathrm{S} 2, \beta$, and $\kappa$-Caseins in Water Buffalo Milk by Reverse Phase-High Performance Liquid Chromatography and Mass Spectrometry. Journal of Agricultural and Food Chemistry, 57, 2988-2992. https://doi.org/10.1021/jf803653v 
[28] SAS (2007) SAS/STAT Software. Version 9 Edition, SAS Inst. Inc., Cary.

[29] Bequette, B., Lapierre, H. and Hanigan, M. (2003) Amino Acid Uptake by the Mammary Gland of Lactating Ruminants. In: D’Mello, J.P., Ed., Amino Acids in Animal Nutrition, Wallingford, 347-365. https://doi.org/10.1079/9780851996547.0347

[30] Nan, X., Bu, D., Li, X., Wang, J., Wei, H., Hu, H., Zhou, L. and Loor, J.J. (2014) Ratio of Lysine to Methionine Alters Expression of Genes Involved in Milk Protein Transcription and Translation and mTOR Phosphorylation in Bovine Mammary Cells. Physiological Genomics, 46, 268-275. https://doi.org/10.1152/physiolgenomics.00119.2013

[31] Awawdeh, M.S. (2016) Rumen-Protected Methionine and Lysine: Effects on Milk Production and Plasma Amino Acids of Dairy Cows with Reference to Metabolisable Protein Status. Journal of Dairy Research, 83, 151-155. https://doi.org/10.1017/S0022029916000108

[32] Mercier, J., Grosclaude, F. and Ribadeau-Dumas, B. (1971) Primary Structure of Bovine s1 Casein. Complete Sequence. European Journal of Biochemistry, 23, 41-51. https://doi.org/10.1111/j.1432-1033.1971.tb01590.x

[33] Fang, Z., Visker, M., Miranda, G., Delacroix-Buchet, A., Bovenhuis, H. and Martin, P. (2016) The Relationships among Bovine aS-Casein Phosphorylation Isoforms Suggest Different Phosphorylation Pathways. Journal of Dairy Science, 99, 8168-8177. https://doi.org/10.3168/jds.2016-11250

[34] Treweek, T.M., Thorn, D.C., Price, W.E. and Carver, J.A. (2011) The Chaperone Action of Bovine Milk $\alpha \mathrm{S} 1$ - and $\alpha \mathrm{S} 2$-Caseins and Their Associated form $\alpha \mathrm{S}$-Casein. Archives of Biochemistry and Biophysics, 510, 42-52. https://doi.org/10.1016/j.abb.2011.03.012

[35] Frederiksen, P., Andersen, K., Hammershøj, M., Poulsen, H., Sørensen, J., Bakman, M., Qvist, K. and Larsen, L. (2011) Composition and Effect of Blending of Noncoagulating, Poorly Coagulating, and Well-Coagulating Bovine Milk from Individual Danish Holstein Cows. Journal of Dairy Science, 94, 4787-4799. https://doi.org/10.3168/jds.2011-4343

[36] Bijl, E., van Valenberg, H., Sikkes, S., Jumelet, S., Sala, G., Olieman, K., van Hooijdonk, T. and Huppertz, T. (2014) Chymosin-Induced Hydrolysis of Caseins: Influence of Degree of Phosphorylation of Alpha-s1-Casein and Genetic Variants of Beta-Casein. International Dairy Journal, 39, 215-221. https://doi.org/10.1016/j.idairyj.2014.07.005

[37] Kimball, S.R. and Jefferson, L.S. (2006) New Functions for Amino Acids: Effects on Gene Transcription and Translation. The American Journal of Clinical Nutrition, 83, 500S-507S. https://doi.org/10.1093/ajcn/83.2.500S

[38] Wedholm, A., Larsen, L.B., Lindmark-Månsson, H., Karlsson, A.H. and Andrén, A. (2006) Effect of Protein Composition on the Cheese-Making Properties of Milk from Individual Dairy Cows. Journal of Dairy Science, 89, 3296-3305. https://doi.org/10.3168/jds.S0022-0302(06)72366-9

[39] Mohanty, D., Mohapatra, S., Misra, S. and Sahu, P. (2016) Milk Derived Bioactive Peptides and Their Impact on Human Health-A Review. Saudi Journal of Biological Sciences, 23, 577-583. https://doi.org/10.1016/j.sjbs.2015.06.005

[40] Baro, L., Jiménez, J., Martínez-Férez, A. and Bouza, J. (2001) Péptidos y proteínas de la leche con propiedades funcionales. Ars Pharmaceutica, 42, 135-145.

[41] Třináctý, J., Kř́ižová, L., Richter, M., Černý, V. and Ř́ha, J. (2009) Effect of Rumen-Protected Methionine, Lysine or Both on Milk Production and Plasma Amino 
Acids of High-Yielding Dairy Cows. Czech Journal of Animal Science, 54, 239-248. https://doi.org/10.17221/1730-CJAS

[42] Pacheco-Rios, D., McNabb, W., Hill, J., Barry, T. and Mackenzie, D. (1999) The Effects of Methionine Supplementation upon Milk Composition and Production of Forage-Fed Dairy Cows. Canadian Journal of Animal Science, 79, 235-241. https://doi.org/10.4141/A98-116 